\title{
The Effectiveness of Civic Education Learning Using the Multimedia Role Playing Model in Developing Student Civic Skills
}

\author{
Apriyanda Kusuma Wijaya ${ }^{1}$, Wulan Andini ${ }^{2}$ \\ \{apriyandawijaya@ syekhnurjati.ac.id ${ }^{1}$, wulanandini@ syekhnurjati.ac.id ${ }^{2}$ \} \\ Tadris of Social Sciences Syekh Nurjati State Islamic Institute, Cirebon ${ }^{1}$, \\ Teacher Education at Madrasah Ibtidaiyah Syekh Nurjati State Islamic Institute, Cirebon ${ }^{2}$

\begin{abstract}
This research aims to determine the effect of Civics learning using role-playing models multimedia on students' citizenship skills. This research uses a quasi-experimental method with a quantitative approach. As a whole, 858 students of SMK Telkom Bandung became the research population. Then for the sample, 36 students of class X Multimedia2 as the experimental class and 36 students of class X Multimedia- 3 as the control class. The results of this research indicate that civic education learning that uses a model is roleplaying effective in developing students' civic skills. The development of civic skills in this study includes the ability to identify problems, describe problems, and take attitudes towards problems.
\end{abstract}

Keywords: Citizenship Education, Citizenship Skills, Role-Playing Models, Multimedia

\section{Introduction}

Citizenship Education is a subject that has the mandate to shape citizen competence. In these citizen competences, there are knowledge of citizenship, citizenship skills, and citizenship character, these terms in learning are commonly referred to as student personalities, attitudes and skills [1],[2], the process of forming citizenship competencies specifically regarding student citizenship skills, such as personality and attitudes, cannot be separated from the role of the teacher in designing the learning process. For this reason, a learning model and media are needed that can stimulate student enthusiasm because if the teacher's delivery is less attractive it will have an impact on students' enthusiasm, intellectual skills, and social participation [3]$[5]$.

Intellectual and social participation are part of civic skills that must be fulfilled in the goal of Citizenship Education [6]-[8]. Based on pre-research conducted by researchers on the implementation of Civics learning at SMK Telkom Bandung, there are several things to note in learning, such as the use of conventional learning models and the inadequate use of multimedia in learning which results in low enthusiasm and student citizenship skills in learning. For this reason, the researcher tries to study using the principles of social learning theory which is the basis for cooperative learning and emphasizes the elements of cooperation social interactions [9]. The implementation of the learning process with elements of cooperation and social interaction is carried out through the application of integrating role-playing models with multimedia learning so that student enthusiasm increases [10]. It is hoped that in addition to an increased enthusiasm, it will also improve students' citizenship skills.

The steps or stages of implementing model learning role-playing this adopt from the steps of implementing the model role-playing with multimedia by developing into the following: The first stage the teacher orientates about the model to be applied to students, 
namely displaying PowerPoint learning materials, related learning videos with learning material and identify its relation to learning material. In the stage second teacher determines the group for the role, namely analyzing the role, selecting the players who will perform the role. In the third stage, the teacher prepares the researcher/student observer, namely deciding what to look for, assigning observation tasks to students. The fourth stage of the implementation of the role is to start playing roles, strengthening role-playing, ending role-playing. The fifth stage discusses and evaluates the roles/reviews the roles and then develops further roles. The sixth stage re-plays, namely playing a changed role, providing input or alternative behavior in the next step. The seventh stage is to share and generalize experiences, namely connecting situations with real-life and other problems, explaining general principles in behavior. The eighth or final stage is to prepare and create learning outcomes, namely rewriting the meaningful roles into the form of group learning videos [11],[12].

Based on the class phenomenon in the pre-research that has been described, the researcher conducted a learning experiment between conventional lecture learning and roleplaying learning that maximized the use of multimedia learning intending to know the impact of learning multimedia role-playing on students' citizenship skills.

\section{Research Method}

Methods used is a quasi-experimental method with a quantitative approach. The research design was pretest and posttest Control Group. The population in this study were students at SMK Telkom Bandung which consisted of 25 class study groups with a total of 858 students. Then in the sample section, it is determined based on the characteristics of the similarity of students in the equivalent class from the class level, the activities and creativity of students in learning [13], namely students in class X Multimedia-2 (36 students) as an experimental class and class X Multimedia-3 (36 students) as a class. control. This research uses observation, tests, and questionnaires as research instruments, before using the instrument has been tested and declared valid with a very good level of reliability. Data analysis using statistical inferential parametric tests with the help of software statistical SPSS 20. Then for the variables in this study, Civic education learning used model role-playing multimedia as the independent variable and student citizenship skills as the dependent variable. The indicators of civic skills include intellectual skills and participation skills [14].

\section{Results and discussion}

Based on the questionnaire that has been distributed, it shows the following graphical data:

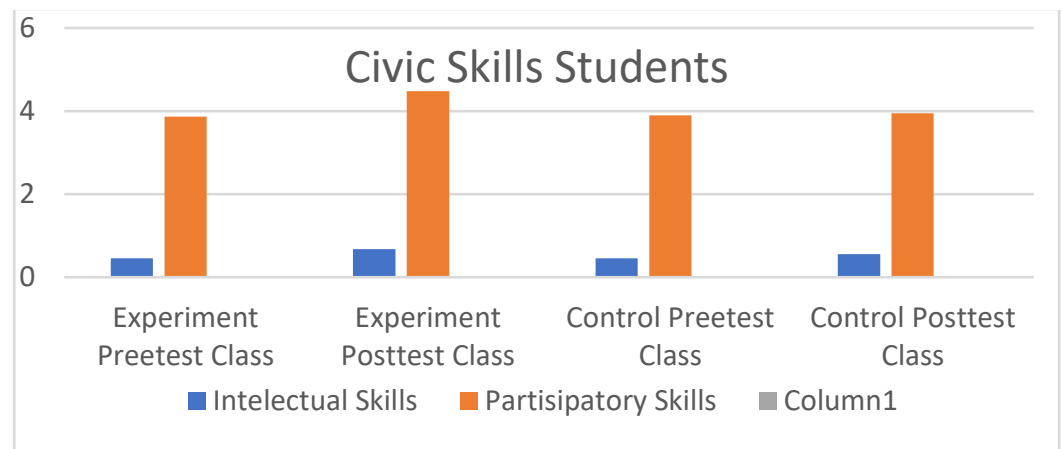

Fig 1. Graph of the average value of the pretest-posttest questionnaire results in the experimental class and control class 
Based on the graphic figure 1 above it is stated in the experimental class the average value of the pretest indicator of intellectual skills of 0.48 and the post-test of 0.68 , the increase is 0.20 . Then for the average value of the participation skill indicator was 3.87 and for the -test the post-test was 4.44 the increase was 0.57 . Furthermore, in the control class, the mean test for intellectual skills ability is 0.46 and the post-test is 0.56 , which has increased by 0.10 . For the mean of participation skills pre-test the control class 3.90 and the post-test is 3.95, the increase is 0.05 .

Based on the data above, it can be understood that the model role-playing multimedia in Civics learning has a significant influence on student citizenship skills, this is indicated by the average value of an increase in intellectual skills of 0.20 or $20 \%$, intellectual skills here include the ability to identify problems. , the ability to describe problems, and take a stand. Then on the participation skills of 0.57 or $57 \%$ which includes general participation skills in discussion, negotiation, socialization, and skills in group problem-solving [15].

The effect can be analyzed of rationality model development, among other things: First, the application of multimedia role-playing models emphasized to explore social values through a private exploration and feelings of students in the environment of cooperation [16].[17]. The principle of cooperation is part of the concept of cooperation in solving problems [18]. Which must be built continuously through character education. The principle of cooperation ideally also adjusts to independence so that cooperation can run well and in balance. Character education is the inheritance of the national values, ideals, and goals that are stated in the state constitution and the message of the founders of the country. In this millennial era, the value of cooperation and independence are values that include being the foundation in building the personality of citizens, this is of course important to continue to be emphasized and implemented in every lesson because it will build positive relationships between friends and train the social cognitive aspects of students [19].

The following is one form of cooperation in learning:

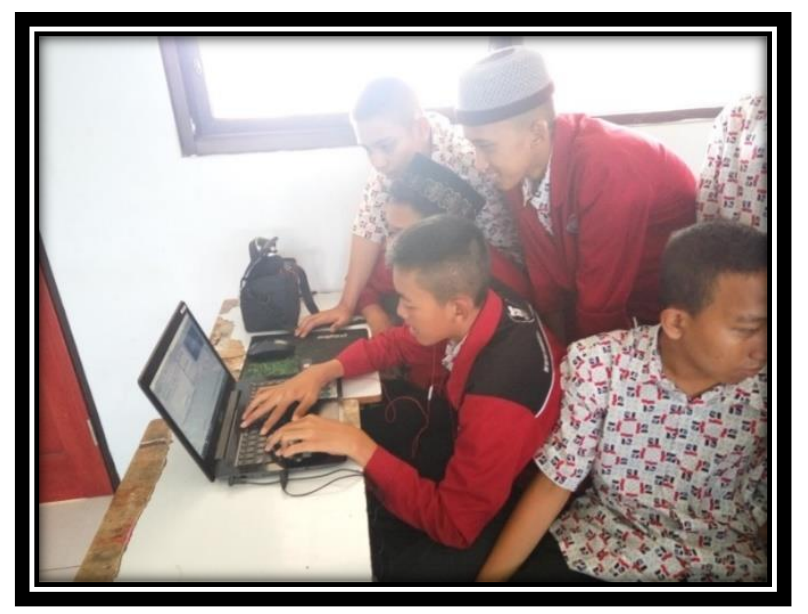

Fig 2. The process of collaboration in making multimedia role-playing video projects

The second rationalization analysis, learning models role-playing multimedia can spur students to think critically, identify behavioral views, and implement what is understood. In other words, the learning will shape and build the meaning of the phenomenon, or the student experience with the physical environment [20]. Through PPKn learning that applies model $a$ roleplaying multimedia-assisted, students not only gain knowledge or cognition, but students will also gain the ability to build their existing knowledge into new knowledge based on their 
new learning experiences. So that PPKn learning does not only develop civic knowledge, in the form of knowledge and understanding of national social culture, government structures and processes, and political life but also develop civic skills. Civic Education learning seeks to emphasize students to be able to process moral knowledge in the form of behavior and skills [21].

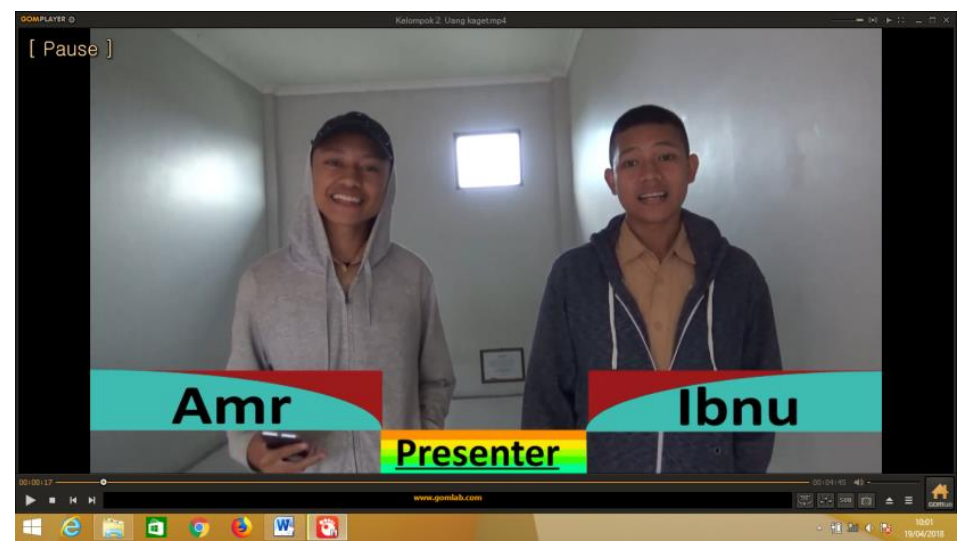

Fig 3. Videos of the results of playing roles in Civics learning

The third rationalization analysis, one of the missions of Civics learning multimedia role-playing is the exploration of subject matter and the learning environment to develop problem-solving skills related to shared responsibilities related to the role and making of learning projects [22]. In implementing project-based learning, it is a PPKn learning model in which there are several methods such as creating an independent classroom and environment atmosphere, participating in associations, managing conflicts, community service, role playing or simulations, character studies, and peaceful demonstrations in practice [23],[24]. In addition, this research also shows the process of mutual respect between students and the creation of learning outcomes projects that are part of the development of the nation's character, and forming citizens with a high-minded culture, with character to prepare a quality generation [25],[26].

To strengthen the assumption of the significance of the application of the multimedia role-playing model in learning, the researcher shows a gain score analysis. analysis Gain score is a way of analyzing data from experimental design to find the value of the difference of values between the pretest-posttest and experimental class and control class. To more clearly understand the comparison, it gains score can be seen from the table below:

Table 1: Gain Score Citizenship Skills

\begin{tabular}{cccccc}
\hline & Kelas & N & Mean & Std. Deviation & $\begin{array}{c}\text { Std. Error } \\
\text { Mean }\end{array}$ \\
\hline \multirow{2}{*}{ gain_score } & Eksperimen & 36 & 9,7778 & 6,09033 & 1,01505 \\
\cline { 2 - 6 } & Kontrol & 36 & 2,3333 & 1,24212 &, 20702 \\
\hline
\end{tabular}

Based on table 1 the difference in the average value of the post-test and pretest results in the experimental class is 9.78 while in the control class it is 2.33 . From this value, it shows that the increase in student citizenship skills in the experimental class is much higher than the control class, which means that the use of the model role-playing has a multimedia significant effect on the improvement of students' citizenship skills. So the application of model the role-playing 
multimedia in Civics learning emphasizes students to also understand the characters of other students through joint decision making when discussing, when carrying out the role process, and when making joint learning outcomes. This is so that students can understand and determine how good character is and how to have a sense of mutual understanding through a learning process [27].

\section{Conclusion}

Based on the results of the analysis that has been carried out on the research methodology, it is found that the T-count value is greater than the T-table, then the $p$-value is 0.00 less than 0.05 . Then $\mathrm{H}_{0}: \mu_{1}=\mu_{2}$ is rejected. So that the average gain value between the experimental class and the control class is different and the first hypothesis can be accepted that there is a significant difference in citizenship skills between students who use the model role-playing multimedia and students who are treated with conventional lecture learning. So it can be concluded that the application of the model is role-playing quite significant and effective in improving students' citizenship skills.

\section{References}

[1] Winataputra, Udin S. (2016). Posisi Akademik Pendidikan Kewarganegaraan (Civic education) dan Muatan/Mata Pelajaran Pendidikan Pancasila Dan Kewarganegaraan (Civic education) Dalam Konteks Sistem Pendidikan Nasional. FKIP Universitas Terbuka dan FPIPS\&SPS Universitas Pendidikan Indonesia. Jurnal Moral Kemasyarakatan. Vol. 1, No.1, Juni 2016

[2] Branson, M.S. (1998). The Role of Civic Education. Calabasas: CCE

[3] Wijaya, A. K. (2020). Integrasi Model Pembelajaran Bermain peran dengan Multimedia Dalam Meningkatkan Keterampilan Partisipasi Sosial Siswa. Edueksos: Jurnal Pendidikan Sosial Dan Ekonomi, 9(1). https://doi.org/10.24235/edueksos.v9i1.6420

[4] Komalasari, K dan Didin Saripudin (2017). Interactive Vallue Based Multimedia Development Trough Integrated Practices for Student Character Building. TOJET: The Turkish Online Journal of Educational Technology - October 2017, volume 16 issue

[5] Wijaya, A.K, dkk.(2020). Kontribusi Pembelajaran Pendidikan Kewarganegaraan Menggunakan Model Bermain peran untuk Pengembangan Keterampilan Intelektual Siswa, Jurnal Pendidikan Civic education. Desember 2020 Volume 1 Nomor 2. https://jurnal.untan.ac.id/index.php/JCivic education/article/view/41253

[6] Komalasari, K dan Budimansyah. (2008). Pengaruh Pembelajaran Kontekstual Dalam Pendidikan Kewarganegaraan Terhadap Kompetensi Kewarganegaraan Siswa SMP. Acta Civicus, Vol. 2, No. 1, Oktober 2008, 77.

[7] Winataputra, Udin dan Dasim Budiansyah. (2012). Pendidikan kewarganegaraan dalam perspektif internasional. Bandung : Widya Aksara Press.

[8] Alison K. Cohen and Benjamin W. Chaffee . (2012). The relationship between adolescents' civic knowledge, civic attitude, and civic behavior and their self-reported futurelikelihood of voting Education, Citizenship and Social Justice. 8(1) 43-57. sagepub.co.uk/journalsPermissions.nav DOI: 10.1177/1746197912456339 esj.sagepub.com

[9] Joyce, Bruce. Dkk. (2009). Models of Teaching (Model-Model Pengajaran). Yogyakarta: Pustaka Pelajar.

[10] Ariwitari,Ni Md Rai. dkk. (2014). Pengaruh Metode Pembelajaran Bermain peran Berbantuan Media Audio Visual Terhadap Hasil Belajar Civic education Kelas V Sd Gugus 1 Tampaksiring. jurnal mimbar pgsd : Universitas Pendidikan Ganesha Jurusan Pgsd (vol: 2 no: 1 tahun 2014

[11] Joyce, Bruce. Dkk. (2009). Models Of Teaching (Model-Model Pengajaran). Yogyakarta: Pustaka Pelajar 
[12] Wijaya, A. K., Rahmat, R., \& Kokom, K. (2018). Reflective Experiences of Students to the Integration of Bermain peran Model with Multimedia in Citizenship Education. 251(Acec), 418 421. https://doi.org/10.2991/acec-18.2018.95

[13] Creswell, John W. 2008. Educational Research: Planning, Conducting, and Evaluating Quantitative and Qualitative Research. New Jersey: Pearson Education Inc

[14] Carmine Maiello, Fritz oser \& Horst Biedermann. (2003). Civic Knowledge, Civic Skills and Civic Engagement. European Educational Research Journal, Volume 2, Number 3, 2003.384. University of

Fribourg, Switzerland.sagepub.co.uk/journalsPermissions.nav.DOI:10.1177/1746197912456339.esj.sagepub .com

[15] Budimansyah, D dan Suryadi, K. (2008). Civic education dan masyarakat Multikultural. Bandung:Program Studi Kewarganegaraan Sekolah Pascasarjana UPI

[16] Joyce, Bruce. Dkk. (2009). Models Of Teaching (Model-Model Pengajaran). Yogyakarta: Pustaka Pelajar.

[17] Wijaya, A. K., Rahmat, R., \& Kokom, K. (2018). Reflective Experiences of Students to the Integration of Bermain peran Model with Multimedia in Citizenship Education. 251(Acec), 418 421. https://doi.org/10.2991/acec-18.2018.95

[18] Sulianti, Raden. (2015). Efektifitas Model Problem best Learning dalam pendidikan pancasila dan kewarganegaraan untuk meningkatkan keterampilan kewarganegaraan siswa. Bandung : Universitas Pendidikan Indonesia

[19] Komalasari, K. (2008). Pengaruh Pembelajaran Kontekstual dalam Civic education Terhadap Kompetensi Kewarganegaraan Siswa SMP. Disertasi Doktor pada Sekolah Pascasarjana Universitas Pendidikan Indonesia Bandung: tidak diterbitkan

[20] Rusmana (2012). Strategi Pembelajaran Dengan Problem Based Learning Untuk Meningkatkan Profesionalitas Guru. Jakarta: Ghalia Indonesia.

[21] Wijaya, A. K. (2018). Pengaruh Model Bermain Peran Berbantuan Multimedia Dalam Pembelajaran Civic education Terhadap Keterampilan Kewarganegaraan Siswa. Universitas Pendidikan Indonesia http://repository.upi.edu/37826/

[22] Hersted, Lone. (2017).Reflective Role-Playing in the Development of Dialogic Skill. Journal of Transformative Education 2017, Vol. 15(2) 137-155. Department of Learning and Philosophy, University of Aalborg, Aalborg, Denmark. The Author(s) 2017 Reprints and permission: sagepub.com/journalsPermissions.nav $\quad$ DOI: $\quad 10.1177 / 1541344616686765$ journals.sagepub.com/home/jtd

[23] Komalasari. K, dan Didin Saripudin. (2017). Pendidikan Karakter Konsep dan Aplikasi Living Values Education. Bandung : Rafika Aditama.

[24] Made Wena. (2009). Strategi pembelajaran inovatif kontemporer: suatu tinjauan konseptual operasional. Jakarta: Bumi Aksara

[25] Suryadi. Ace,(2009). Mewujudkan Masyarakat Pembelajar: Konsep, Kebijakan dan Implementasi. Bandung: Widya Aksara Press.

[26] Lickona, T. (2012). Educating for Character: How Our School Can Teach Respect and Responsibility (Mendidik untuk Membentuk Karakter). Cetakan Pertama. Diterjemahkan oleh: Uyu Wahyudin. Jakarta: PT. Bumi Aksara

[27] Daniau, Stéphane. (2016). The Transformative Potential of Role-Playing Games: From Play Skills to Human Skills. Simulation \& Gaming 2016, Vol. 47(4) 423-444. 1Université du Québec à Montréal, Canada (c) The Author(s) 2016 Reprints and permissions: sagepub.com/journalsPermissions.nav DOI: 10.1177/1046878116650765 sag.sagepub.com 